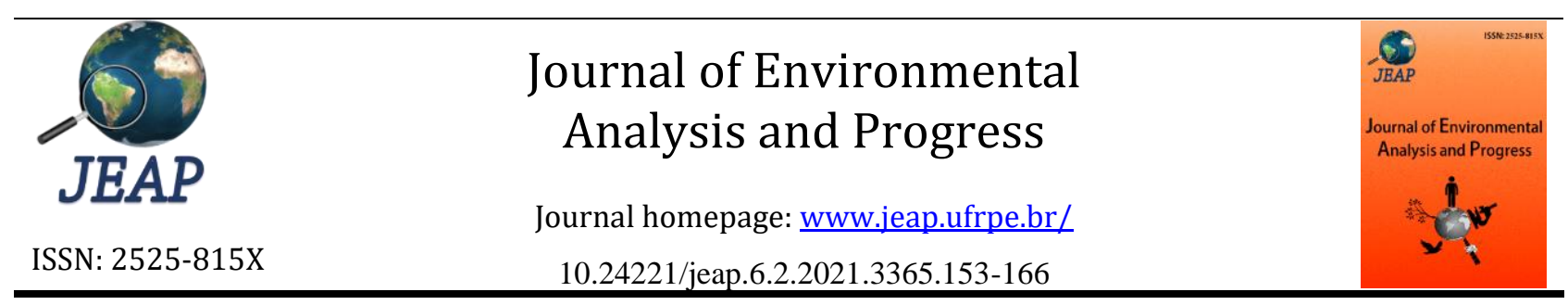

\title{
Interaction of macroinvertebrates in leaf litter in forest ecosystems: a review
}

\author{
Cinara Wanderléa Felix Bezerra ${ }^{a}$, Luciana de Matos Andrade ${ }^{a}$ \\ ${ }^{\text {a }}$ Universidade Federal Rural de Pernambuco, Unidade Acadêmica de Serra Talhada. Av. Gregório Ferraz Nogueira, Serra \\ Talhada, Pernambuco, Brasil. CEP: 56909-535. E-mail: cinarawfb@gmail.com, luciana_matos1@ @hotmail.com.
}

\begin{tabular}{l}
\hline A R T I C L E I N F O \\
\hline Recebido 08 Jan 2019 \\
Aceito 11 Jun 2021 \\
Publicado 30 Jun 2021
\end{tabular}

\begin{abstract}
A B S T R A C T
Leaf litter consists of vegetables (e.g., leaves, fruit, twigs) and animal debris/debris. It acts in soil fertilization through its decomposition and fragmentation by abiotic and biotic factors (such as bacteria, fungi, invertebrates, and vertebrates), which help in the nutrient cycling process, making it an alternative to the recovery of degraded areas. This research aims to survey information on the interactions of litter fauna with forest environments, considering the main groups and their contributions to nutrient cycling and soil fertilization in degraded areas. For the elaboration of the research, extensive research was carried out using the academic Google, Science Direct, and Scopus platforms, where it was possible to gather information about the action of the litter fauna in the formation, fragmentation, decomposition, and fertilization of the soil. Litter production varies according to the climatic conditions in the region. There is a greater production in tropical and subtropical regions and semi-arid regions due to the deciduous capacity of plants in dry periods, allowing greater deposition of biomass in the soil. The litter acts as a shelter for a high faunal diversity. Among them the most representative ones are Annelida (Oligochaeta), Myriapoda (Chilopoda/Diplopoda), Hexapoda (Diptera, Hemiptera, Orthoptera, Coleoptera, Blattodea, Isoptera, Hymenoptera, Lepidoptera, Isopoda, Thysanura), Cheliceriformes Araneae, Scorpiones, Pseudoscorpiones, and Opiliones), Mollusca (Gastropoda). All these factors make litter a source of nutrients rich in organic compounds that help improve soil fertility and provide the animals that inhabit it with a universe of ecological niches suited to the needs of each species.
\end{abstract}

Keywords: Biomass, decomposition, invertebrates, nutrients, soil.

\section{Introduction}

Leaf litter, also called soil biomass, is defined as material from vegetative areas deposited in the soil, resulting from the fall of leaves (representing 50\%), the bark of trees, branches, sticks, fruits, flowers, seeds, among other elements (Figueiredo Filho et al., 2003; Costa et al., 2010; Souza et al., 2017 / Santos et al., 2019), as well as by animal residues, which are in various stages of decomposition (Silva et al., 2017).

The leaf litter production is determined from abiotic factors (altitude, light, temperature, precipitation, climate, relief, water availability, soil properties), biotic (deciduousness and type of vegetation), and latitudinal (Menezes et al., 2010). However, depending on the ecosystem in which the leaf litter is found, some factors may stand out from others (Figueiredo Filho et al., 2003). Among these factors, the climate is the most important for its production since it is linked to plant production and, consequently, with the decomposition time of the biomass accumulated in the soil (Bray; Gorham, 1964; Keiser \& Bradford, 2017; Moreira \& Silva, 2004; Zhang et al., 2015).

The leaf litter also acts as a regulator of water infiltration in the soil, making it possible to carry and the nutrients cycling for this medium (Mateus et al., 2013), favoring the exchange of minerals between living beings and the environment, in addition to serving as soil fertilizer, is widely used in the recovery of degraded areas (Ashford et al., 2013; Cunha Neto et al., 2013), as well as acting in the conservation of the species found in it, as it houses many dormant seeds and a large invertebrate diversity (Costa et al., 2010) and some vertebrates.

Vertebrates consist of the edaphic fauna, reptiles, amphibians, and mainly invertebrates, related to the fragmentation and decomposition of the material that makes up the leaf litter (Mahon et al., 2020), providing natural fertilization soil (Moço et al., 2005). It is worth mentioning that the 
amount of leaf litter and, consequently, its nutritional potential, will reflect on the productive and recovery capacity of the soil, as these factors will cause physical and chemical changes in the soil structure, arising from the organic matter deposited in it (Schumacher et al., 2004).

The presence of fauna in the leaf litter depends on the layers of these that are deposited in the soil, where characteristically in the deepest strata of this biomass, there is a greater concentration of animals (Dick \& Schumacher, 2015), with $82 \%$ of the described species represented by arthropods (Lewinsohn, Freitas \& Prado, 2005). This arthropod fauna helps, especially, in the conservation, monitoring, and restoration of the natural resources of these environments (Lewinsohn \& Freitas; Prado, 2005), acts as seed dispersers, decomposers, parasites, producers, pollinators, assist in nutrient cycling, in addition to acting as bioindicators of environmental changes, as they are sensitive to changes in ecosystems (Maestri et al., 2013). The distribution and diversity of taxa are directly linked to seasonality, contributing to the formation of vegetation cover in the soil (Lima et al., 2020; Silva et al., 2020).

Most of these arthropods feed on dead organic matter, effectively participating in the mineralization of nutrients, transforming organic matter into inorganic matter associated with decomposers. As a result, they are considered the primary agents of leaf litter fragmentation, influencing ecosystem processes, changing the soil's physical, chemical, and biological structure, and the primary productivity of plants (Maestri et al., 2013).

This research aims to survey information on the interactions of litter fauna with forest environments, taking into account the main groups and their contributions to nutrient cycling and soil fertilization in degraded areas.

\section{Materials and Methods}

This qualitative study is a literature review aiming to gather information about litter functions in the litter formation, fragmentation, and decomposition process in vegetative environments directly related to nutrient cycling, consequently associated with soil fertilization. This understanding provides a broad view of the importance of these faunal groups for the balance of the ecosystem and provides us with insight into the use of litter and fauna to recover degraded areas. For the elaboration of this research, extensive research was carried out using the keywords: litter fauna; litter decomposition; litter deposition and fragmentation; arthropod fauna.
Google Scholar, Science Direct, and Scopus platforms were used to search for scientific articles. In addition, books were used as a source of essential information.

\section{Importance of leaf litter}

One of the first studies in Brazil on leaf litter was found in the book entitled: "Memory about the foundation and funding of a farm in the province of Rio de Janeiro" by Werneck, dated in 1863, which highlights leaf litter as a means of verifying the quality of the land, showing that large amounts of leaf litter and a wide variety of vegetation are necessary prerequisites for the land to be considered of good quality.

Since then, several works have been developed to verify the decomposition of the leaf litter (Duarte, 2017; Gripp et al., 2018); production (Bray; Gorham, 1964; Rosa et al., 2017); the association with nutrient cycling (Moraes; Domingos, 1997; Silva et al., 2009), quality (Haridasan, 2000; Souza et al., 2017) and fauna (Elton, 1973; Amaral, 2017), these factors being studied, predominantly in Atlantic Forest environments (Vidal et al., 2007; Machado et al., 2015); from Cerrado (Silva et al., 2007; Mudrek \& Massoli-Junior, 2014) and caatinga (Alves et al., 2006; Lima et al., 2015; Maia, 2016).

Concerning the level of importance, leaf litter can be used to recover degraded areas (Martins et al., 2018) since it facilitates water infiltration into the soil (Coelho Netto, 2003), reducing erosion processes controlling the impact of rain directly on the soil. In addition, it improves the physical conditions of the environment (Mitchell \& Tell, 1977), regulates humidity, soil temperature (Ferreira; Marques, 1998), and serves as a shelter for several vertebrates and invertebrate animals (Facelli \& Facelli, 1993). Its deposition in the soil introduces spatial and temporal heterogeneity in the environment, affecting the dynamics and structure of the community (Molofsky \& Augspurger, 1992), provide retention of high amounts of nutrients and through its decomposition can be considered an important source of devolution of these nutrients to the soil (Vital et al., 2004; Caldeira et al., 2006), constitute an important pathway of the biogeochemical cycle, mainly in soils with high weathering, and plant biomass becomes the main and most important reservoir of nutrients.

Among the organisms present in the leaf litter, arthropods stand out for playing a fundamental role in the regulation of natural and agricultural systems, acting in the processes of humification, mineralization, and decomposition of organic materials; in the aggregation and 
structuring of the soil; in the mobilization and immobilization of micro and macronutrients and, consequently, in the regulation and conservation of diseases and pests, favoring production systems (Devide \& Castro, 2009).

\section{Leaf litter production, deposition, and decomposition}

In tropical forests, leaf litter production occurs continuously throughout the year, and the amount produced in different seasons depends on the vegetation type and its response to these seasonal variations (Giacomo, Pereira \& Machado, 2012). There are estimates that leaf litter production in tropical and subtropical forests is around 10,165.13 kg.ha-1 (Arato, Martins \& Ferrari, 2003), indicating a slight increase in riparian forest areas (marginal vegetation in rivers and streams) registering $10,503 \mathrm{~kg} \cdot \mathrm{ha}^{-1}$, providing a greater translocation of nutrients (Teixeira et al., 2016), which consequently causes an increase in soil fertility. Furthermore, it is worth noting that this high leaf litter production promotes a reduction in the silting up of rivers, acts as pollutant filters, acts as a shelter for various animals that grow and reproduce there, which through the fragmentation of plant material, automatically assist in the decomposition of leaf litter (Chabaribery et al., 2008). In the Cerrado, the decomposition of leaf litter presents variations about to the time required for all biomass to decompose, which directly influences the nutrient contents in soils that generally have low fertility and are classified as dystrophic Latosol with high concentrations of aluminum (Al) (Inkotte et al., 2019).

The caatinga is located in a region with a semi-arid climate, which is characterized by water deficit, arising from several factors, highlighting the high light intensity, which favors the increase in temperature and, consequently, causes the desiccation of the soil due to the high rate evaporation (Alves, 2009; Santos et al., 2011). Thus, as a result of these environmental conditions, the plants belonging to the Caatinga Domain developed physiological and morphological adaptations (Trovão et al., 2007) and can be mentioned: deciduous properties, annual herbaceous, the predominance of shrubs and discontinuous canopy cover, trees of small size, succulence, aculeus, and thorns (Brand, 2017).

Thus, the characteristic deciduous present in the Caatinga vegetation becomes one of the main elements for soil maintenance and fertilization. During rainy periods, vegetation has a high metabolism, high regenerative capacity through sprouting, rapid response, and a high growth rate (Riegelhaupt et al., 2010). However, in periods of drought, where water availability is very low; and as a way to avoid water loss, the vegetation loses its leaves, allowing the formation of leaf litter, a fact that favors the reduction of water evaporation present in the soil and offers habitats for several animals that act in the fragmentation and decomposition of biomass soil and act in the movement of nutrients present in it (Silva et al., 2007). Among these animals, there is the arthropod fauna that has been researched by some authors (Maia, 2016).

The seasonal pattern of leaf litter deposition in the agroforestry system is marked by maximum production at the end of the dry season, a typical pattern in semideciduous seasonal forests, which has its peak leaf deposition at this time of year as a response to vegetation to climatic seasonality (Arato, Martins \& Ferrari, 2003). The amount of leaf litter deposited in the soil is directly related to climatic conditions. Unlike the hot and humid equatorial regions, the cold regions have lower yields, in which the highest yields occur (Bray \& Gorham, 1964). However, it is possible to observe a large leaf litter production during the spring (Woiciechowski \& Marques, 2017). Forests located in alpine or arctic regions produce approximately one ton per hectare annually, cold temperate forests $\left(3.5\right.$ ton.ha $\left.{ }^{-1}\right)$, equatorial forests (11 ton.ha $\left.{ }^{-1}\right)$, and warm temperate forests $(5,5$ ton.ha ${ }^{-1}$ ) (Bray \& Gorham, 1964).

In Brazil, the amount of leaf litter in the seasonal forests of the southern region reaches several tons per hectare (Pereira; De Menezes \& Schultz, 2008), producing about 14,715.97 kg.ha ${ }^{-1}$ (Vital et al., 2004) and 8,212 kg.ha ${ }^{-1}$ (Pimenta et al., 2011). In the Cerrado, the largest leaf litter production occurs during the dry season (Silva et

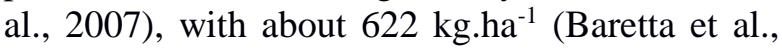
2007) and 5,646.9 kg.ha-1 (Cianciaruso et al., 2006). In the Caatinga, production is $2,068.55$ kg.ha ${ }^{-1}$ (Santana \& Souto, 2011) and 4,038.79 kg.ha ${ }^{-1}$ (Moura et al., 2016). However, according to Silva et al. (2017a), the number of studies evaluating leaf litter deposition is still very scarce.

The decomposition of leaf litter is characterized by the effective return of nutrients to the soil, and the cycling of nutrients defines this nutritional quantity released by the vegetation. This decomposition is influenced mainly by the temperature and the relative humidity of the air. In tropical forests, in winter, there is a decrease in the deposition rate (Santos et al., 2020) and decomposition of leaf litter due to low temperatures, making the process of nutrient cycling difficult and, therefore, there is a decrease in the return of these nutrients to vegetation (Terror, Sousa \& Kozovits, 2011). 
However, a different situation occurs in Caatinga environments, due to the water deficit and long periods of drought, the rate of decomposition is higher in rainy periods (Silva et al., 2009), this happens due to higher values of precipitation and air humidity, which favor the increase of microbiological (bacteria and fungi) and fauna activities in the leaf litter and, consequently, benefit the nutrient cycling.

In periods of drought, decomposition occurs slowly (Alves et al., 2006), the vegetation is typically low, containing shrubs and small trees, which, for the most part, have twisted stems and have thorns (Córdula, Queiroz \& Alves, 2008), in addition to the fact that the vegetation loses its leaves (deciduous characteristic), which accumulate in the soil, favoring an increase in the volume of leaf litter (Silva et al., 2009). However, due to the semi-arid climate of the region, temperatures remain high during periods of drought, and the relative humidity remains low, leaving the leaf litter dry, which inevitably hinders its decomposition and adequate nutrient cycling (Alves et al., 2006).

In addition, it is worth mentioning that other factors can influence the decomposition of the leaf litter, among them: the physical-chemical environmental conditions, the quality (organic and nutritional) of the substrate (Cassart et al., 2020), and the characteristics of the macro habits and microorganisms present in the leaf litter, commonly called the decomposing community, which directly assist in the fragmentation of the leaf litter allowing the entry of nutrients into the soil in an easy and accelerated way (Souto et al., 2013).

In the forest areas that are in early stages, there is a tendency to produce a more rigid leaf litter since the type of vegetation presents anatomical characteristics of spacious palisade parenchyma and with a high amount of sclerenchymatous tissues, a fact that diverges from forest areas that are in more advanced stages of succession (Boeger \& Wisniewski, 2003). As a result, the action of decomposers, represented mainly by arthropods, on this type of leaf litter, slows down the decomposition process, as these animals find it difficult to carry out their activities, including that of leaf litter fragmentation (Andrade et al., 1999; Selle, 2007), slowly decomposing in environments with early stages (Odum, 1969; Toledo et al., 2002; Xuluc-Tolosa et al., 2002), especially in the forest edge region (Casenave et al., 1995; Hill \& Curran, 2001).

Leaf litter acts as a habitat for several species of invertebrates that make up the edaphic fauna. External factors influence the individuals that form this community: temperature, soil moisture, and leaf litter thickness (Moço et al., 2005; Silva et al., 2009) as also the vegetation that makes up this soil biomass (Pereira et al., 2013), which is directly related to the types of species found in each environment.

In forests with an advanced succession stage, it is possible to observe a greater diversity of fauna present in the leaf litter, especially invertebrates, concerning forests in the initial succession stage (Moço et al., 2005; Menezes et al., 2009). However, this variation in the indices of abundance and richness of invertebrate populations may vary according to the dynamics of the edge, that is, according to the environmental conditions (abiotic factors and morphophysiological characteristics of the vegetation that are components of the leaf litter), available to these animals (Carvalho \& Vasconcelos, 1999).

Therefore, it is possible to affirm that the diversity of the communities present in the leaf litter can be altered according to the edge effect of the forest area, where the abundance and richness of species will be affected, factors of great importance for the determination of fauna diversity of an environment (Pereira et al., 2013). Thus, it is necessary to develop new studies investigating what other factors may also influence the fauna dynamics found in the leaf litter.

\section{Leaf litter performance in nutrient cycling}

Leaf litter is responsible for storing high amounts of nutrients (Vendramini et al., 2014; Garlet et al., 2019; Momolli et al., 2019), which after the decomposition process exerted by edaphic fauna and microorganisms return to the soil, being reabsorbed by plants, a fact that directly influences the maintenance of forest ecosystems (Silva et al., 2007; Costa et al., 2019).

According to Souza et al. (2018), it is of fundamental importance to check the nutritional quality of the leaf litter, mainly of its leaves, since with low nutritional quality in this biomass, a small number of nutrients will be fixed in the soil and consequently absorbed by the plants.

The leaf litter nutritional quality can be assessed through the $\mathrm{C}$ : $\mathrm{N}$ ratio, one of the most important indicators for this type of analysis (Souza et al., 2018). According to Silva et al. (2009), plants that have high amounts of nitrogen have a low $\mathrm{C}$ : $\mathrm{N}$ ratio in their residues, a fact that provides a more accelerated decomposition and, therefore, a high rate of nitrogen mineralization for plants.

The nitrogen concentration in the soil biomass does not change according to the periods of the year (e.g., rainy and dry). However, it was 
observed that different parts of the plants might have different concentrations of $\mathrm{N}$, such as, for example, the leaves may have a higher nitrogen concentration compared to branches, which in turn may have higher concentrations of calcium, as well as tree bark (Alves et al., 2017).

Some organisms, especially fungi and bacteria, act directly in the cycling of nutrients and, consequently, in the fixation of these compounds in the soil, mainly nitrogen. Thus they are fundamental to maintain the balance in the availability of these nutrients for the vegetation and the soil (Jardim et al., 2018; Osono, 2019).

The primary nutrients found in leaf litter and which are extremely important for the development of vegetation, are represented by macronutrients, among them: $\mathrm{C}, \mathrm{H}, \mathrm{O}, \mathrm{N}, \mathrm{P}, \mathrm{K}, \mathrm{Ca}$, $\mathrm{Mg}$ and $\mathrm{S}$; and by the micronutrients: $\mathrm{B}, \mathrm{Cl}, \mathrm{Cu}, \mathrm{Fe}$, $\mathrm{Mn}, \mathrm{Mo}, \mathrm{Zn}$, and $\mathrm{Ni}$, which are found in constant transference in ecosystems and in the soil-plant system, which absorbs nutrients from the soil to be used in its metabolism and, later, they return to the soil through the deposition of leaf litter (Vargas et al., 2018, Carvalho et al., 2019; Silva et al., 2019).

\section{Importance of Functional Groups of leaf litter fauna}

The studies by Silva \& Amaral (2013), Brown et al. (2015), and Dias et al. (2019) demonstrated that the leaf litter invertebrate macrofauna reaches $10 \mathrm{~mm}$ in length or more than $2 \mathrm{~mm}$ in body diameter, represented by those macroscopic and that use the soil-leaf littervegetation system as habitat.

This macrofauna consists of the following taxons: Annelida - Oligochaeta (earthworms); Mollusca - Gastropoda (snails); Arthropoda: Hexapoda - Blattodea (cockroaches), Coleoptera (adult and larval beetles), Diptera (mosquitoes and fly larvae), Hemiptera (bedbugs and cicadas), Hymenoptera (ants), Isoptera (termites), Orthoptera (crickets), Thysanura (moths); Arthropoda: Crustacea - Isopoda (little garden bug); Arthropoda: Myriapoda - Diplopoda (snake lice or millipedes), Chilopoda; Arthropoda: Cheliceriformes - Acari (mites), Araneae (spiders), Opiliones ("stinking spiders"), Pseudoscorpionida (false scorpions or book scorpions) and Scorpiones (scorpions) (Silva \& Amaral, 2013; Brown et al., 2015; Silva et al., 2019; Cousseau et al., 2020).

The leaf litter arthropod fauna has a wealth of functional groups summarized by phylum/subphylum (Table 1).

Table 1. Summarized representation of some leaf litter arthropod fauna representatives, describing the phylum/subphylum, functional groups, and bibliographic sources.

\begin{tabular}{|c|c|c|}
\hline $\begin{array}{l}\text { Phylum / } \\
\text { Subphylum }\end{array}$ & $\begin{array}{l}\text { Functional } \\
\text { groups }\end{array}$ & $\begin{array}{c}\text { Bibliographic } \\
\text { source }\end{array}$ \\
\hline $\begin{array}{l}\text { Arthropoda / } \\
\text { Hexapoda }\end{array}$ & $\begin{array}{l}\text { Decomposers, } \\
\text { cadavers, } \\
\text { coprophages, } \\
\text { microbivores, } \\
\text { phytophages, } \\
\text { rhizophagous, } \\
\text { predators and } \\
\text { saprophages. }\end{array}$ & $\begin{array}{l}\text { Lavelle et al. } \\
\text { (2001); Teixeira et } \\
\text { al. (2002); } \\
\text { Vasconcellos } \\
\text { (2005); Baretta et } \\
\text { al. (2011); Brown } \\
\text { et al. (2015). }\end{array}$ \\
\hline $\begin{array}{l}\text { Arthropoda/ } \\
\text { Myriapoda }\end{array}$ & $\begin{array}{l}\text { Detritivores, } \\
\text { geophagous, } \\
\text { coprophages, } \\
\text { insectivores and } \\
\text { predators. }\end{array}$ & $\begin{array}{l}\text { Baretta et al. } \\
(2011) .\end{array}$ \\
\hline $\begin{array}{l}\text { Arthropoda/ } \\
\text { Cheliceriformes }\end{array}$ & $\begin{array}{l}\text { Insectivores, } \\
\text { decomposers, and } \\
\text { predators. }\end{array}$ & $\begin{array}{l}\text { Poggiani et al. } \\
\text { (1996); Prendini } \\
\text { (2005); Tizo- } \\
\text { Pedroso (2007); } \\
\text { Martins et al. } \\
\text { (2008). }\end{array}$ \\
\hline
\end{tabular}

Some components of the macrofauna, specifically earthworms, scarab beetles, ants, termites, and millipedes, are often called "soil engineers", because they can alter and modify the physical and chemical characteristics of the soil through the production of biogenic structures such as canals, nests, tunnels, fecal acorns, galleries and chambers, structures that modify the distribution and supply of nutrients to other organisms and plants (Brown et al., 2015).

Oligoquete annelids (earthworms) have detritivorous and geophagous eating habits, adding high importance to the nutrient cycling process since they interfere with the decomposition of organic waste (Bartz et al., 2009). In addition, the ants also act as agents of leaf litter transformers due to their locomotion. Earthworms also promote the formation of tunnels, facilitating the movement of other soil fauna groups and improve the distribution of water in the soil profile (Lazcano \& Dominguez, 2011), promoting an increase in soil moisture, which in turn favors the germination of seeds present inside the galleries/tunnels. According to Lavelle et al. (2001), some species can be classified as epigeic species.

The species belonging to this ecological niche inhabit the upper layers of the soil and the lower leaf litter and are able to adapt easily in environments unfavorable to their growth and development, being exposed to droughts and extreme temperatures. However, the earthworm species that have a pigmented body do not create galleries in the soil, as they preferentially live inside or in the upper part of the leaf litter where they find better quality food; they have even higher 
growth rates; they are more vulnerable to their predators, due to exposure (Baretta et al., 2011).

Leaf litter is considered to be the main maintenance agent for the communities of these oligochaetes, playing a more important role than the roots of plants (Chen et al., 2020). Earthworms are considered potentially important as bioindicators of soil contamination. However, it is cautious to evaluate species, ecological categories, environmental conditions, and analogies with other organisms (Andréa, 2010).

Gastropod mollusks (snails) are in a trophic position between detritivores and decomposers, contributing significantly to the cycling of nutrients and are potentially important in mineralization and energy transfer processes in leaf litter (Baker, 2001).

According to Strom (2004), there is widespread agreement among researchers that the low dispersal ability of land snails, in association with their dependence on a stable microclimate, makes many species excellent indicators of the qualities of the environments. However, Baker (2001) mentioned that a large part of the diversity of terrestrial gastropods is still unknown, mainly the small detritivorous mollusks of the leaf litter.

The wild species of blatódeos (cockroaches) are detritivorous, omnivorous and some species can present predatory habits. However, wild species preferentially feed on the material of animal origin (Grandcolas \& Pellens, 2012), inhabit hot and humid places in the leaf litter, as well as are found in the bark of trees and nests of termites and ants (Teixeira et al., 2002).

Coleoptera (beetles) are cosmopolitan insects of different sizes and have different eating habits: predators, rhizophagous, phytophagous, and saprophagous (Baretta et al., 2011; Brown et al., 2015). Coleoptera, especially representatives of the Scarabaeidae family, dig and accumulate organic matter in the soil at different depths, making them fundamental to their environment (Louzada, 2008). There is a direct relationship between the size of these individuals and the amount of organic matter that is incorporated into the soil, and it is observed that the larger the individual, the greater the capacity of organic matter it incorporates (Horgan, 2001).

Diptera (flies and mosquitoes) are insects that have decomposing habits, pollinators and can be used as biological controllers. Specimens can be found mainly flying or landed on stems, foliage, treetops, in the nests of various animals, including other insects, moving on the substrate, on leaves, fruits, seeds, soil, and leaf litter (Rafael, 2002).

Currently, there is a consensus in the literature that insects stand out as organisms potentially used as bioindicators (Alves \& Gabriel, 2016), due to their high perceptual capacity, primarily about to changes in the environment, due to their advanced sensory system, which enables them to qualify environmental conditions in different situations and, also, to quantify damages caused to the environment (Oliveira et al., 2014). Therefore, according to Oliveira et al. (2014), the potentially important orders for use in environmental monitoring programs are Coleoptera, Diptera, Hemiptera, Hymenoptera, Lepidoptera, and Orthoptera.

Hymenopterans (ants, wasps, and bees), specifically ants, are social insects that live in colonies and termites. Functional groups of this order are considered predators, phytophages, and saprophages, playing fundamental roles in the structuring of the soil, through the construction of anthills (or nests), the formation of underground galleries, in addition to assisting in the transport of organic matter from the surface of the anthill, for its interior, a fact that determines the storage and distribution of water in the soil, facilitated by the drainage channels made by these animals.

Among the soil microarthropods, ants are considered the most important, as they regulate populations and the biological control of several plant species (Vasconcellos, 2005). They are usually found in branches that are one of the most used resources by ants, and it is possible to find complete colonies inside the cavities (Fernandes et al., 2019). Orthopterans (crickets and grasshoppers) have a phytophagous feeding habit, feeding on various plant materials, and some species of this taxon have enormous economic importance since they are considered pests in agricultural plantations, causing losses to productivity (Vasconcelos, 2005).

Thysanura (moths) are insects that have a food preference for the organic matter of plant origin, inhabit humid places, and are commonly found under rocks, leaf sheaths, branches, bark bark, between decaying leaves and under rotting wood accumulated in the soil, moving between cracks, pores or at the soil interface (Giracca et al., 2003).

Isopods are small crustaceans that live on leaf litter and are among macro arthropods with horizontal displacement in the soil. This characteristic promotes the redistribution of organic matter and, consequently, nutrients in a given area. On the other hand, there are macro arthropods in the leaf litter that move vertically, where a redistribution in the soil profile is easily observed, leading to an increase in the heterogeneity of the area, and, therefore, the formation of a mosaic of small patches of soil with 
varied fertilities (Brown et al., 2002; Campos-Filho et al., 2014).

Myriapods (centipedes) stands out as one of the leaf litter macrofauna taxa that can act at different trophic levels, directly influencing the dynamics of these environments (Santos-Silva et al., 2018). The Diplopoda have different eating habits: detritivores, geophagous, and coprophages promote the incorporation of leaf litter, directly affecting soil properties (Toyota et al., 2006). Chilopods are nocturnal; they feed basically on worms and beetle larvae, preferentially living in humid places with low temperatures. In Brazil, there are few studies conducted with this group. However, there are indications that they are efficient in use as bioindicators (Baretta et al., 2011)

Scorpionids (scorpions) are considered functional groups with carnivorous eating habits, with food preferences that vary according to the species, size, type, size of prey, and amount of food available. However, they feed mainly on insects (cockroaches and crickets), and some species may exhibit cannibalistic behavior (Martins et al., 2008). Due to their sensitivity, they are considered important elements of ecological studies since they are affected by a series of limiting factors such as the cover of leaf litter and stones, temperature, topography, precipitation, characteristics of the soil and rocks, as well as the type of vegetation and the physiognomy of the environment (Prendini, 2005).

Araneae (spiders) commonly feed on insects, have nocturnal habits and great environmental adaptability, acting as regulators of the edaphic communities (Poggiani et al., 1996). Some studies indicate that there are families of spiders that are indicators of soil quality and that the presence or absence of certain families can indicate the degree of anthropic intervention in forests (Baretta et al., 2007).

Pseudoscorpions are small arachnids found in leaf litter, under rocks, tree bark, dead trunks, caves, and other similar environments. They feed on small animals and have a hunting and feeding behavior that varies according to the morphology of their chelicerae and following the presence or absence of venom glands, thus regulating animal populations (Tizo-Pedroso, 2007).

Opiliones (harvestmen) are considered detritivores and feed on tiny animals, with a high degree of endemism and high sensitivity to environmental changes, acting effectively in the cycling of soil organic matter and with low dispersion capacity among most species (Santos, 2016).
Its distribution, composition, and density vary according to its size, the depth and locality in the soil, and the seasons (Lavelle \& Spain, 2001). Mites usually feed on fungi, decomposing organic matter, and algae; they are considered the smallest groups that constitute the edaphic fauna (Baretta et al., 2011). They are commonly abundant in the layers of organic matter compared to the mineral layer of the soil (Petersen \& Luxton, 1982). Dust mites are the main components of the edaphic mesofauna. They are important in the ecological processes of decomposition of organic matter since they act in the process of fragmentation of smaller particles, facilitating their entry into the soil, as well as they can also serve to monitor different management systems cultivation and evaluate changes in the biological quality of the soil (Rieff et al., 2014).

The total number of mite individuals sampled in a given area and the quantitative analysis of diversity has currently been the focus of several fauna studies, thus allowing the characterization of a community (Uramoto et al., 2005).

Thus, it can be seen that biodiversity studies are highly fundamental, as they seek to attribute values through "indexes" (e.g., wealth, abundance, and heterogeneity) to facilitate environmental assessments, allowing environments from different locations to be compared and better understood (Lavelle et al., 2006), being considered as measures of the "qualitative dispersion" of a population, which make it possible to measure the qualitative variability of individuals, belonging to qualitatively different categories (Pielou, 1977; Martins \& Santos, 1999).

\section{Conclusion}

Leaf litter plays a positive role in various environments, making it extremely important for maintaining soil quality, since it acts as a source of nutrients, enabling a continuous biogeochemical cycle; it prevents the direct impact of the rains, regulating the flow of water to the soil and provides a barrier against water loss, due to solar radiation directly affecting the soil. Given these benefits, leaf litter is considered paramount in the recovery of degraded areas, making it a viable and highly efficient alternative.

Furthermore, because their production and deposition vary according to the chemical, physical and biological characteristics of the forest systems, the diversity and richness of the fauna species also vary since the type of vegetation, the climatic factors, and the thickness of the leaf litter are 
directly associated with the diversity of invertebrates that can be found in this soil biomass.

The functional fauna groups that live in the leaf litter use it as a shelter for development and reproduction because they find adequate environmental conditions to create several ecological niches that allow their permanence.

The most representative animals found in the leaf litter are arthropods (e.g., Chelicerata, insects, and myriapods). However, other groups of invertebrates can be found, such as earthworms and gastropod mollusks. Together, these animals help the leaf litter fragmentation, help the decomposition process and, consequently, assist in nutrient cycling, as they are processes of fundamental importance in soil maintenance and nutrition.

The action of this macrofauna in the cycling of nutrients allows the relationships between the chemical compounds existing in the leaf litter to be intermediated in an accelerated way due to the fragmentation arising from the life habits of these animals, helping in the maintenance of the physical-chemical interactions of the forest environments.

It is also worth mentioning that the climatic factors, among them: temperature, relative humidity, precipitation, and luminosity, influence the leaf litter functionality, directly interfering in the time of deposition and decomposition, as well as in the richness of macroinvertebrate species because different species are adapted to different environmental conditions.

Therefore, it is important to develop new fauna studies, which make it possible to comprehensively understand the diversity and richness of species living in the leaf litter of different vegetative environments, seeking to find out how these species assist in the physicalchemical processes involved in the leaf litter functionality. Through these researches, there will be a greater understanding of the importance of these animals to the environment and what their contributions are to different ecosystems.

\section{Referências}

Alves, A. R.; Ferreira, R. L. C.; Silva, J. A. A.; Dubeux-Junior, J. C. B.; Salami, G. 2017. Nutrientes na biomassa aérea e na serapilheira em áreas de caatinga em Floresta, PE. Pesquisa Florestal Brasileira, 37, 92, 413420. https://doi.org/10.4336/2017.pfb.37.92.1060

Alves, A. R.; Santos, J. B.; Souto, P. C.; Holanda, A. C. 2006. Aporte e decomposição de serrapilheira em área de Caatinga, na Paraíba. Revista de Biologia e Ciências da Terra, 6, 2,
194-203.

Alves, J. J. A. 2009. Degradação da caatinga: uma investigação ecogeográfica. Revista Caatinga, 22, 3, 126-135.

Alves, M. I. B.; Gabriel, J. L. C. 2016. Composição da mimercofauna de um fragmento de cerrado em regeneração em Botucatu, São Paulo. Forum Ambiental, 12, 01, 107-117. http://dx.doi.org/10.17271/19800827121201 61367

Amaral, T. C. 2017. Invertebrados epígeos como indicadores de recuperação de área degradada tratada com lodo de esgoto e resíduos de poda de árvores. Dissertação de Mestrado. Universidade de Brasília, Brasília. Brasil. $81 \mathrm{p}$.

Andrade, A. G.; Caballero, S. S. U.; Faria, A. M. 1999. Ciclagem de nutrientes em ecossistemas florestais. Rio de Janeiro, EMBRAPA Solos, Documentos n. 13, 22p.

Andréa, M. M. 2010. O Uso de minhocas como bioindicadores de contaminação de solos. Acta Zoológica Mexicana, Número Especial, 2, 2, 95-107. https://doi.org/10.21829/azm.2010.262874

Arato, H. D.; Martins, S. V.; Ferrari, S. H. de S. 2003. Produção e decomposição de serapilheira em um sistema agroflorestal implantado para recuperação de área degradada em Viçosa-MG. Revista Árvore, 27, 5, 715-721. https://doi.org/10.1590/S010067622003000500014

Ashford, O. S.; Foster, W. A.; Turner, B. I.; Sayer, E. J.; Sutcliffe, L.; Tanner, E. V. J. 2013. Litter manipulation and the soil arthropod community in a lowland tropical rainforest. Soil Biology and Biochemistry, 62, 5-12. https://doi.org/10.1016/j.soilbio.2013.03.001

Baker, G. M. 2001. Gastropods on land: phylogeny, diversity and adaptative morphology. In: Baker, G. M. (ed.). The biology of terrestrial molluscs. New York, CABI. pp. 1-146.

Baretta, D.; Brescovit, A. D.; Knysak, I.; Cardoso, E. J. B. N. 2007. Trap and soil monolith sampled edaphic spiders (Arachnida: Araneae) in Araucaria angustifolia forest. Scientia Agricola, 64, 4, 375-383. https://doi.org/10.1590/S010390162007000400008

Baretta, D.; Santos, J. C. P.; Segat, J. C.; Geremia, E. V.; Oliveira-Filho, L. C. I.; Alvez, M. V. 2011.Fauna edáfica e qualidade do solo. Tópicos em Ciência do Solo, January, 119170.

Bartz, M. L. C.; Brown, G. G.; Pasini, A.; 
Fernandes, J. O.; Dorioz, J.; Ralisch, R. 2009. Earthworm communities in organic and conventional coffee cultivation. Pesquisa Agropecuária Brasileira, 44, 8, 928-933. https://doi.org/10.1590/S0100204X2009000800019

Boeger, M. R. T.; Wisniewski, C. 2003. Comparação da morfologia foliar de espécies arbóreas de três estádios sucessionais distintos de floresta ombrófila densa (Floresta Atlântica) no Sul do Brasil. Revista Brasileira de Botânica, 26, 1, 61-72. https://doi.org/10.1590/S010084042003000100007

Brand, M. A. 2017. Potencial de uso da biomassa florestal da caatinga, sob manejo sustentável, para geração de energia. Ciência Florestal, 27, 1 , 117-127. https://doi.org/10.5902/1980509826452

Bray, J. R.; Gorham, E. 1964. Litter production in forests of the world. Advances in Ecological Research, 2, C, 101-157. https://doi.org/10.1016/S00652504(08)60331-1

Brown, G. G.; Niva, C. C.; Zagatto, M. R. G.; Ferreira, S. A.; Nadolny, H. S.; Cardoso, G. B. X.; Santos, A.; Martinez, G. A.; Pasini, A.; Bartz, M. L. C.; Sautter, K. D.; Thomazini, M. J.; Baretta, D.; Silva, E.; Antoniolli, Z. I.; Decaens, T.; Lavelle, P. M.; Souza, J. P.; Carvalho, F. 2015. Biodiversidade da fauna do solo e sua contribuição para os serviços ambientais. Serviços Ambientais em Sistemas Agrícolas e Florestais do Bioma Mata Atlântica. EMBRAPA. pp. 122-154.

Caldeira, M. V. W.; Watzlawick, L. F.; Soares, R. V.; Valério, A. F. 2006. Teores de micronutrientes em espécies arbóreas da floresta ombrófila mista Montana - General Carneiro/PR. Ambiência, 2, 1, 29-50.

Campos-Filho, I. S.; Araujo, P. B.; Bichuette, M. E.; Trajano, E.; Taiti, A. 2014. Terrestrial isopods (Crustacea: Isopoda: Oniscidea) from Brazilian caves. Zoological Journal of the Linnean Society, 172, 2, 360-425. https://doi.org/10.1111/zoj.12172

Carvalho, K. S.; Vasconcelos, H. L. 1999. Forest fragmentation in central Amazonia and its effects on litter-dwelling ants. Biological Conservation, 91, 2-3, 151-157. https://doi.org/10.1016/S00063207(99)00079-8

Carvalho, H. C. S.; Ferreira, J. L. S.; Calil, F. N.; Silva-Neto, C. N. 2019. Estoque de nutrientes na serapilheira acumulada em quatro tipos de vegetação no Cerrado em Goiás, Brasil. Ecologia e Nutrição Florestal, 7, 6, 1-11.
https://doi.org/10.5902/2316980X37296.

Cassart, B.; Basia, A. A.; Jonard, M.; Ponette, Q. 2020. Average leaf litter quality drives the decomposition of single-species, mixedspecies and transplanted leaf litters for two contrasting tropical forest types in the Congo Basin (DRC). Annald Forense Science, 77, 2, 1-33. https://doi.org/10.1007/s13595-02000942-4

Casenave, J. L.; Pelotto, J. P.; Protomastro, J. 1995. Edge-interior differences in vegetation structure and composition in a Chaco semiarid forest, Argentina. Forest Ecology and Management, 72, 1, 61-69. https://doi.org/10.1016/03781127(94)03444-2

Chen, Y.; Cao, J.; He, X.; Liu, T.; Shao, Y.; Zhang, C.; Zhou, Q.; Li, F.; Mao, P.; Tao, L.; Liu, Z.; Lin, Y.; Zhou, L.; Zhang, W.; Fu, S. 2020. Plant leaf litter plays a more important role than roots in maintaining earthworm communities in subtropical plantations. Soil Biol. Biochem., 144, May 2020, 107777. https://doi.org/10.1016/j.soilbio.2020.10777 7

Cianciaruso, M. V.; Pieres, J. S. R.; Delitti, W. B. C.; Silva, E. L. F. P. 2006. Produção de serapilheira e decomposição do material foliar em um cerradão na Estação Ecológica de Jataí, município de Luiz Antônio, SP, Brasil. Acta Botanica Brasilica, 20, 1, 49-59. https://doi.org/10.1590/S010233062006000100006

Coelho Netto, A. 2003. Evolução de Cabeceiras de Drenagem no médio vale do rio Paraíba do Sul (SP/RJ): Bases para um modelo de formação e crescimento da rede de canais sob controle estrutural. Revista Brasileira de Geomorfologia, 4, 2, 69-100. http://dx.doi.org/10.20502/rbg.v4i2.25

Córdula, E.; Queiroz, L. P.; Alves, M. 2008. Checklist da flora de Mirandiba, Pernambuco: Leguminosae. Rodriguésia, 59, 3, 597-602. https://doi.org/10.1590/21757860200859313

Costa, C. C. A.; Camacho, R. G. V.; Macedo, I. D.; Silva, P. C. M. 2010. Análise comparativa da produção de serapilheira em fragmentos arbóreos e arbustivos em área de caatinga na FLONA de Açu-RN. Revista Árvore, 34, 2 , 259-265. https://doi.org/10.1590/S010067622010000200008

Costa, G. S.; Gama-Rodrigues, A. C.; Cunha, G. D. M. 2005. Decomposição e liberação de nutrientes da serapilheira foliar em povoamentos de Eucalyptus grandis no norte fluminense. Revista Árvore, 29, 4, 563-570. 
https://doi.org/10.1590/S0100-

67622005000400008

Costa, C. P.; Costa, S. C.; Cunha, C. N. 2019. Comparação da Produção da Serapilheira e Fenologia em dois Macro-habitat Florestais no Pantanal, Mato Grosso, Brasil. Biodiversidade Bras., 9, 2, 97-110.

Cousseau, L.; Tessaro, D.; Vargas, R. F. Silva, J. C.; Kubiak, K. L. 2020. Levantamento de invertebrados epiedáficos em ambiente contaminado por chumbo. Revista. Soc. Dev., 9, 3, 1-21. http://dx.doi.org/10.33448/rsdv9i3.2738

Cunha Neto, F. V.; Leles, P. S. S.; Pereira, M. G.; Bellumath, V. G. H.; Alonso, J. M. 2013. Acúmulo e decomposição da serapilheira em quatro formações florestais. Ciência Florestal, $23, \quad 3, \quad 379-387$. https://doi.org/10.5902/1980509810549

Devide, A. C. P.; Castro, C. M. De. 2009. Manejo do solo e a dinâmica da fauna edáfica. Disponível em: http://www.infobibos.com/Artigos/2009_1/ ManejoSolo/index.htm

Dias, S.; Wilian, R.; Lima, S.; Augusto, C.; Araujo, K. D. 2019. Mesofauna invertebrada na interface solo + serapilheira, em Maceió, Alagoas Invertebrate mesofauna atthesoil interface + litter, in Maceió, Alagoas. Revista Craibeiras Agroecologia, 4, 1-6.

Dick, G.; Schumacher, M. V. 2015.Relações entre solo e fitofisionomias em florestas naturais. Revista Ecologia e Nutrição Florestal ENFLO, 3, 3, 31-39. http://dx.doi.org/10.5902/2316980X16741

Duarte, C. F. 2017. Influência de borda no banco de sementes de serapilheira de um remanescente de Floresta Estacional Semidecidual no Sul do Brasil. Trabalho de Conclusão de Curso. Universidade Federal de Integração Latino-Americana. Foz do iguaçu. Brasil. 55p.

Elton, C. S. 1973. The structure of invertebrate populations inside neotropical rain forest. The Journal of Animal Ecology, 42, 1, 55-104. https://doi.org/10.2307/3406

Facelli, J. M.; Facelli, E. 1993. Interactions after death: plant litter controls priority effects in a successional plant community. Oecologia, 95, 2, 277-282. https://doi.org/10.1007/BF00323500

Ferreira, R. L.; Marques, M. M. 1998. A Fauna de Artrópodes de Serrapilheira de Áreas de Monocultura com Eucalyptus sp. e Mata Secundária Heterogênea. Anais da Sociedade Entomológica do Brasil, 27, 3, 395-403. https://doi.org/10.1590/S0301-

\section{7}

Figueiredo Filho, A.; Moraes, G. F.; Schaaf, L. B.; Figueiredo, D. J. 2003. Avaliação estacional da deposição de serapilheira em uma floresta ombrófila mista localizada no sul do estado do Paraná. Ciência Florestal, 13, 1, 11-18. https://doi.org/10.5902/198050981718

Garlet, C.; Schumacher, M. V.; Dick, G.; Viera, M. 2019. Ciclagem de nutrientes em povoamento de Eucalyptus dunnii Maiden: produção de serapilheira e devolução de macronutrientes no bioma Pampa. Ecol. e Nutr. Florest, 7, 2, 1-9. https://doi.org/10.5902/2316980X37057

Giacomo, R. G.; Pereira, M. G.; Machado, D. L. 2012. Aporte e decomposição de serapilheira em áreas de cerradão e mata mesofítica na estação ecológica de Pirapitinga-MG. Ciência Florestal, 22, 4, 669-680. https://doi.org/10.5902/198050987549

Giracca, E. M. N.; Antoniolli, Z. I.; Eltz, F. L. F.; Benedetti, E.; Lasta, E.; Venturinni, S. F.; Benedetti, T. 2003. Levantamento da Meso e Macrofauna do Solo na Microbacia do Arroio Lino, Agudo/RS. Revista Brasileira Agrociência, 9, 3, 257-261. http://dx.doi.org/10.18539/cast.v9i3.604

Grandcolas, P.; Pellens, R. Blattaria Burmeister, 1829. In: Rafael, J. A.; Melo, G. A. R.; Carvalho, C. J. B.; Casari, S. A.; Constantino, R. [Ed.]. 2012. Insetos do Brasil: diversidade e taxonomia. Ribeirão Preto: Holos. pp. 333346.

Gripp, A. R.; Esteves, F. A.; Carneiro, L. S.; Guariento, R. D.; Figueiredo-Barros, M. P.; Coq, S.; Mircu, A.; Caliman, A. 2018. Weak to no effects of litter biomass and mixing on litter decomposition in a seasonally dry tropical forest. Pedobiologia, 68, 20-23. https://doi.org/10.1016/j.pedobi.2018.02.003

Hill, J. L.; Curran, P. J. 2001. Species composition in fragmented forests: Conservation implications of changing forest area. Applied Geography, 21, 2, 157-174.

Horgan, F. G. 2001. Burial of bovine dung by coprophagous beetles (Coleoptera: Scarabaeidae) from horse and cow grazing sites in El Salvador. European Journal of Soil Biology, 37, 2, 103-111.

Inkotte, J.; Martins, R. C.; Scardua, F. P.; Pereira, R. S. 2019. Métodos de avaliação da ciclagem de nutrientes no bioma Cerrado : uma revisão sistemática Methods of evaluation of nutrient cycling in the Cerrado biome: a systematic review Resumo $\mathrm{O}$ entendimento do funcionamento e variáveis que influenciam a estabilidad. Ciência Florestal, 29, 2, 9881003. 
https://doi.org/10.5902/1980509827982

Jardim, A. M. R. J.; Silva, J. R.I.; Leite, M. L. M. V.; Teixeira, V. I.; Morato, R. P.; AraujoJunior, G. N.; Silva, T. G. F. 2018. Symbiotic interaction in forage crop cultivations: A review. Amazonian Journal of Plant Research, 2, 1, 149-160. https://doi.org/10.26545/ajpr.2018.b00019x

Keiser, A. D.; Bradford, M. A. 2017. Climate masks decomposer influence in a cross-site litter decomposition study. Soil Biology and Biochemistry, 107, 180-187. https://doi.org/10.1016/j.soilbio.2016.12.022

Lavelle, P.; Decaens, T.; Aubert, M.; Barot, S.; Blouin, M.; Bureau, F.; Margerie, P.; Mora, P.; Rossi, J. P. 2006. Soil invertebrates and ecosystem services. European Journal of Soil Biology, 42, 1. 3-15. https://doi.org/10.1016/j.ejsobi.2006.10.002

Lavelle, P.; Spain, A. V. 2001. Soil Ecology. Kluwer Academics Publishers, Dordrecht, Netherlands, 654p. https://doi.org/10.1007/0306-48162-6

Lazcano, C.; Domínguez, J. 2011. The use of vermicompost in sustainable agriculture: impact on plant growth and soil fertility. In: Miransari, M. (Ed.). Soil nutrients. New York: Nova Science Publishers. pp. 230-254.

Lewinsohn, T. M.; Freitas, A. V. L.; Prado, P. I. 2005. Conservation of Terrestrial Invertebrates and Their Habitats in Brazil. Conservation Biology, 19, 3, 640-645. https://doi.org/10.1111/j.1523-

1739.2005.00682.x

Lima, C. de S.; Dalzochio, M. S.; Silva, E. F. de; Périco, E. 2020. Macrofauna edáfica e sua relação com sazonalidade em sistema de uso do solo, bioma cerrado. Rev. IberoAmericana Ciências Ambientais, 11, 2, 1-13. https://doi.org/10.6008/CBPC21796858.2020.002.0001

Lima, R. P.; Fernandes, M. M.; Fernandes, M. R. M.; Matricardi, E. A. T. 2015. Aporte e decomposição da serapilheira na Caatinga no Sul do Piauí. Floresta e Ambiente, 22, 1, 42 49. https://doi.org/10.1590/21798087.062013

Louzada, J. N. C. 2008. Scarabaeinae (Coleoptera: Scarabaeidae) detritívoros em ecossistemas tropicais: diversidade e serviços ambientais. In: Moreira, F. M. S.; Siqueira, J. O.; Brussaard, L. Biodiversidade do solo em ecossistemas Brasileiros. Editora da Universidade Federal de Lavras, pp. 299-322.

Machado, D.; Pereira, M. G.; Correia, M. E. F.; Diniz, A. R.; Santos, L. L.; Menezes, C. E. G. 2015. Ciclagem de nutrientes em diferentes estágios sucessionais da Mata Atlântica na bacia do rio Paraíba do Sul, RJ. Biosci. J., 31, 4, 1222-1237. https://doi.org/10.14393/BJv31n1a2015-23092

Maestri, R.; Leite, M. A. S.; Schmitt, L. Z.; Restello, R. M. 2013. Efeito de mata nativa e bosque de eucalipto sobre a riqueza de artrópodos na serrapilheira. Perspectiva, Erechim., 37, Edição Especial, 31-40.

Mahon, M. B.; Fisk, M. C.; Crist, T. O. 2020. Interactive Effects of White-Tailed Deer, an Invasive Shrub , and Exotic Earthworms on Leaf Litter Decomposition. Ecosystems, 23, 1523-1535. https://doi.org/10.1007/s10021020-00485-9

Maia, L. S. 2016. Artrópodes de solo habitantes da Caatinga sob manejo florestal (fazenda Alvorada, São Gonçalo do Amarante, Ceará). Dissertação de Mestrado. Universidade Federal do Ceará, Centro de Ciências Agrárias, Departamento de Fitotecnia. Ceará. Brasil. 59p.

Martins, F. R.; Santos, F. A. M. 1999. Técnicas usuais de estimativa da biodiversidade. Ed. Holos, 1, 236-267.

Martins, M. R. R.; Rafaine, D.; Neves, M. F.; Sacco, S. R. 2008. Escorpiões: Biologia E Acidentes. Revista Científica Eletrônica de Medicina Veterinária, 10, 1-7.

Martins, W. B. R.; Ferreira, G. C.; Souza, F. P.; Dionisios, F. L. S.; Oliveira, F. A. 2018. Deposição de serapilheira e nutrientes em áreas de mineração submetidas a métodos de restauração florestal em Paragominas, Pará. Floresta, $\quad 48, \quad 1, \quad 37-48$. http://dx.doi.org/10.5380/rf.v48i1.49288

Mateus, F. A.; Miranda, C. C.; Valcarcel, R.; Figueiredo, P. H. A. 2013. Estoque e capacidade de retenção hídrica da serrapilheira acumulada na restauração florestal de áreas perturbadas na mata atlântica. Floresta e Ambiente, 20, 3, 336343. https://doi.org/10.4322/floram.2013.024 Menezes, C. E. G.; Pereira, M. G.; Correia, M. E. F.; Anjos, L. H. C.; Paula, R. R.; Souza, M. E. 2010. Aporte e decomposição da serapilheira e produção de biomassa radicular em florestas com diferentes estágios sucessionais em Pinheiral, RJ. Ciência Florestal, 20, 3, 439452. https://doi.org/10.5902/198050982059

Mitchell, W. H.; Tell, M. R. 1977. Winter-annual cover crops for no-tillage corn production. Agron. J., 69, 4, 569-573. https://doi.org /10.2134/agronj1977.0002196200690004001 $1 \mathrm{x}$

Moço, M. K. S.; Gama-Rodrigues, E. F.; GamaRodrigues, A. C.; Correia, M. E. F. 2005. 
Caracterização da fauna edáfica em diferentes coberturas vegetais na região norte fluminense. Revista Brasileira de Ciência do Solo, 29, 4, 555-564. https://doi.org/10.1590/S010006832005000400008

Molofsky, J.; Augspurger, C. K. 1992. The effect of leaf litter on early seedling establishment in a tropical forest. Ecology, 73, 1, 68-77. https://doi.org/10.2307/1938721

Momolli, D. R.; Schumacher, M. 2019 Sustentabilidade de povoamentos de Acacia mearnsii De Wild. em diferentes idades: uma revisão da ciclagem de nutrientes. Rev. Bras. Gestão Ambient. e Sustentabilidade, 6, 12, 263-272.

https://doi.org/10.21438/rbgas.061220

Moraes, R. M.; Domingos, M. 1997. Elementos minerais em folhas de espécies arbóreas de Mata Atlântica e Mata de Restinga, na Ilha do Cardoso, SP. Revista Brasileira de Botânica, $20, \quad 2, \quad 133-138$. https://doi.org/10.1590/S010084041997000200004

Moreira, P. R.; Silva, O. A. 2004. Produção de serapilheira em área reflorestada. Revista Árvore, 28, 1, 49-59. https://doi.org/10.1590/S010067622008000100016

Moura, M. M. S.; Costa, G. B. R.; Palácio, H. A. Q.; Araujo-Neto, J. R.; Brasil, J. B. 2016. Produção de serapilheira e suas frações em área da Caatinga no Semiárido Tropical. Revista Brasileira de Gestão Ambiental e Sustentabilidade, 3, 5, 199-208. https://doi.org/10.21438/rbgas.030509

Mudrek, J. R.; Massoli E. V., J. 2014. Estrutura da comunidade de artrópodes de solo em diferentes fitofisionomias da reserva particular do patrimônio natural - Sesc Pantanal, Brasil. Holos, 30, 1, 60-67. https://doi.org/10.15628/holos.2014.1622

Odum, E. P. 1969. The strategy of ecosystem development. Science, 164, 262-270.

Oliveira, M. A.; Gomes, C. F. F.; Pires, E. M.; Marinho, C. G. S.; Lucia, T. M. C. D. 2014. Bioindicadores ambientais: Insetos como um instrumento desta avaliação. Revista Ceres, 61, 800-807.

Oliveira, T.; Gomes, C. F. F.; Pires, E. M.; Marinho, C. G. S.; Lucia, T. M. C. D. 2014. Bioindicadores ambientais: insetos como um Instrumento desta avaliação. Revista Ceres, 61, 800-807.

Osono, T. 2019. Functional diversity of ligninolytic fungi associated with leaf litter decomposition. Ecological Reseach, 35, 1-14. https://doi.org/10.1111/1440-1703.12063

Pereira, G. H. A.; Pereira, M. G.; Anjos, L. H. C.; Amorim, T. A.; Menezes, C. E. G. 2013. Decomposição da serapilheira, diversidade e funcionalidade de invertebrados do solo em um fragmento de Floresta Atlântica. Bioscience Journal, 29, 5, 1317-1327.

Pereira, M. G.; Menezes, L. F. T.; Schultz, N. 2008. Aporte e decomposição da serapilheira na Floresta Atlântica, Ilha da Marambaia, Mangaratiba, RJ. Ciência Florestal, 18, 4, 443-454. https://doi.org/10.5902/19805098428

Petersen, H.; Luxton, M. A. 1982. Comparative analysis of soil fauna populations and their role in decomposition processes. Oikos, 39, 3, 288-388. https://doi.org/10.2307/3544689

Pielou, E. C. 1975. Ecological Diversity. John Wiley and Sons., 165p. https://doi.org/10.4319/lo.1977.22.1.0174b

Pimenta, J. A.; Rossi, L. B.; Torezan, J. M. D.; Cavalheiros, A. L.; Bianchini, E. 2011. Produção de serapilheira e ciclagem de nutrientes de um reflorestamento e de uma floresta estacional semidecidual no sul do Brasil. Acta Botanica Brasilica, 25, 1, 53-57. https://doi.org/10.1590/S010233062011000100008

Poggiani, F.; Oliveira, R. E.; Cunha, G. C. 1996. Práticas de ecologia florestal. Piracicaba, pp. 1-44.

Prendini, L. 2005. Scorpion diversity and distribution in southern Africa: pattern and process. African Biodiversity. pp. 25-68.

Pope, C. A.; Halvorson, H. M.; Francoeur, S. N.; Kuehn, K. A.; Findlay, R. H. 2020. Light and temperature mediate algal stimulation of heterotrophic activity on decomposing leaf litter. Freshwater Biological, 1, 3, 1-13. https://doi.org/10.1111/fwb.13465

Uromato, K.; Walder, J. M. M.; Zucchi, R. A. 2005. Análise quantitativa e distribuição de populações de espécies de Anastrepha (Diptera: Tephritidae) no Campus Luiz de Queiroz, Piracicaba, SP. Neotropical Entomology, 34, 1, 33-39. https://doi.org/10.1590/S1519566X2005000100005

Rafael, J. A. 2002. A amostragem. Protocolo e técnicas de captura de diptera. Proyecto de Red Iberoamericana de Biogeografía y Entomología Sistemática. pp. 301-304.

Reis, M. G. F.; Barros, N. F. 1990. Ciclagem de nutrientes em plantios de eucalipto. In. Barros, N. F.; Novais, R. F. (eds.). Relação solo-eucalipto. Viçosa: Ed. Folha de Viçosa, pp. 265-302. 
Rieff, G. G.; Costa, B. C.; Sá, E. L. S. 2014. Potencial bioindicador dos ácaros e colêmbolos: uso dos índices de diversidade na avaliação da qualidade do solo em áreas sob cultivo convencional e orgânico de citros. In: X Reunião Brasileira de Ciência do Solo, Fatos e Mitos em Ciência do Solo. pp. 15-17.

Rosa, T. D. F. de D.; Scaramuzza, W. L. M. P.; Feitosa, I. P.; Abreu, F. F. M. 2017. Produção e decomposição de serapilheira em povoamentos de teca no estado de Mato Grosso, Brasil. Ciência Florestal, 27, 4, 1117 1127. https://doi.org/10.5902/1980509830288

Santana, J. A. S.; Souto, J. S. 2011. Produção de serapilheira na Caatinga da região semi-árida do Rio Grande do Norte, Brasil. Idesia (Arica), 29, 2, 87-94. http://dx.doi.org/10.4067/S071834292011000200011

Santos, F. D.; Fantinel, R. A.; Andrzejewski, C.; Santos, E. L.; Machado, D. N.; Schumacher, M. V. 2020. Litter Accumulation in a Eucalyptus grandis Plantation, Rio Grande do Sul, Brazil. Floresta e Ambiente, 27, 1, e20171106. https://doi.org/10.1590/21798087.110617

Santos, G. L.; Pereira, M. G.; Corrêa Neto, T. A.; Mendonça, V. M. M.; Menezes, C. E. G. 2019. Ciclagem de nutrientes em diferentes condições topográficas em Floresta Estacional Semidecidual, Pinheiral-RJ Nutrient cycling in different topographic conditions in Semideciduous Forest, Pinheiral - RJ state Introdução. Ciência Florestal, 29, 4, 1737-1747. https://doi.org/10.5902/1980509826880

Santos, J. C.; Leal, I. R.; Almeida-Cortez, J. S.; Fernandes, G. W.; Tabarelli, M. 2011. Caatinga: The scientific negligence experienced by a dry tropical forest. Tropical Conservation Science, 4, 3, 276-286. https://doi.org/10.1177/19400829110040030 6

Santos-Silva, L.; Pinheiro, T. G.; Chagas-Jr., A.; Marques, M. I.; Battirola, L. D. 2018. Temporal and spatial variation of Myriapoda (Diplopoda and Chilopoda) assemblages in a neotropical floodplain. Biota Neotrop., 18, 2 , 1-10. https://doi.org/10.1590/1676-0611-bn2018-0514

Schumacher, M. V.; Brun, E. J.; Hernandes, J. I.; Konig, F. G. 2004. Produção de serapilheira em uma floresta de Araucaria angustifolia (Bertol.) Kuntze no município de Pinhal Grande-RS. Revista Árvore, 28, 1, 29-37.

Selle, G. L. 2007. Ciclagem de nutrientes em ecossistemas florestais. Bioscience Journal, 23, 4, 29-39.

Silva, C. A. R.; Lima, R. W. S.; Dias, D. S.; Lira, E. S.; Araujo, K. D. 2019. Macrofauna invertebrada presente no compartimento serapilheira, em acumulada sobre o solo nos ambientes. Revista Craibeiras Agroecologia, $4,1-5$.

Silva, C. J.; Lobo, F. A.; Bleich, M. E.; Sanches, L. 2009. Contribuição de folhas na formação da serrapilheira e no retorno de nutrientes em floresta de transição no norte de Mato Grosso. Acta Amazonica, 39, 3, 591-600. https://doi.org/10.1590/S0044-

59672009000300014

Silva, C. J.; Sanches, L.; Bleich, M. E.; Lobo, F. A.; Nogueira, J. S. 2007. Produção de serrapilheira no cerrado e floresta de transição Amazônia-cerrado do Centro-Oeste brasileiro. Acta Amazonica, 37, 4, 543-548. https://doi.org/10.1590/S004459672007000400009

Silva, D. C.; Pereira, J. M.; Ortiz, D. C.; Oliveira Filho, L. C. I.; Pinto, L. V. A. 2020. Edaphic fauna as a soil quality indicator in forest fragments and coffee growing area. Brazilian Journal Development, 6, 3, 14795-14816. https://doi.org/10.34117/bjdv6n3-375

Silva, L. N.; Amaral, A. A. 2013. Amostragem da mesofauna e macrofauna de solo com armadilha de queda. Revista Verde de Agroecologia e Desenvolvimento Sustentável, 8, 108-115.

Silva, W. B.; Périco, E.; Cajaiba, R. L. 2019. Composição de nutrientes na coberturas florestais no estado do Pará, norte do Brasil. Revista da Universidade Vale do Rio Verde, 17, 1 , 1-8. http://dx.doi.org/10.5892/ruvrd.v17i1.5237

Silva, W. T. de M. et al. 2017. Deposição de serapilheira em áreas de caatinga no núcleo de desertificação do Seridó. Agropecuária Científica no Semiárido, 12, 4, 383-390. http://dx.doi.org/10.30969/acsa.v12i4.861

Souto, P. C.; Souto, J. S.; Santos, R. V.; Bakke, I. V.; Sales, F. C. V.; Souza, B. V. 2016. Rate of litter decomposition and microbial activity in an area of caatinga. Cerne, 19, 4, 559-565.

Souza, M. de S.; Jardim, A. M. R. F.; AraújoJunior, G. N.; Silva, J. R. I.; Leite, M. L. M. V.; Teixeira, V. I.; Silva, T. G. F. 2018. Ciclagem de nutrientes em ecossistemas de pastagens tropicais. Pubvet, 12, 5, 1-9. https://doi.org/10.1590/S010477602013000400005

Souza, M. P. 2017. Qualidade da serapilheira em área de caatinga submetida a plano de manejo 
florestal. Agropecuária Científica no Semiárido, 12, 3, 319-324. http://dx.doi.org/10.30969/acsa.v12i3.856

Ström, L. 2004. Long-term effects of riparian clearcutting - richer land snail communities in regenerating forests. M.S. Thesis. Umeå, Sweden: Umeå University. 23p.

Teixeira, P. R.; Ferreira, R. Q. S.; Camargo, M. O.; Silva. R. R.; Souza, P. B. 2016. Produção de serapilheira de duas fisionomias do domínio Cerrado, Gurupi, Tocantins. pp. 45-50.

Teixeira, R. L.; Coutinho, E. S. 2002. Hábito alimentar de Proceratophrys boiei (Wied) (Amphibia, Anura, Leptodactylidae) em Santa Teresa, Espírito Santo, sudeste do Brasil. Boletim do Museu de Biologia Mello Leitão, 14, 13-20.

Terror, V. L.; Sousa, H. C. de; Kozovits, A. R. 2011. Produção, decomposição e qualidade nutricional da serapilheira foliar em uma floresta paludosa de altitude. Acta Botanica Brasilica, 25, 1, 113-121. https://doi.org/10.1590/S010233062011000100014

Tizo-Pedroso, E. 2007. História natural e comportamento no pseudoescorpião social Paratemnoides nidificator (Balzan, 1888) (Arachnida): Cuidado parental, cooperação e divisão de trabalho. Universidade Federal de Uberlândia, São Paulo. Brasil. 87p.

Toyota, A.; Kaneko, N.; Ito, M. T. 2006. Soil ecosystem engineering by the train millipede Parafontaria laminata in a Japanese larch forest. Soil Biology and Biochemistry, 38, 7, 1840-1850.

https://doi.org/10.1016/j.soilbio.2005.12.015

Trovão, D. M. de B. M.; Fernandes, P. D.; Andrade, L. A.; Dantas Neto, J. 2007. Variações sazonais de aspectos fisiológicos de espécies da Caatinga. Revista Brasileira de Engenharia Agrícola e Ambiental, 11, 3, 307311. https://doi.org/10.1590/S141543662007000300010

Uramoto, K.; Walder, J. M. M.; Zucchi, Vargas, G. R. de; Bianchin, J. E; Blum, H; Marques, R. 2018. Ciclagem de biomassa e nutrientes em plantios florestais. Pesquisa Aplicada \& Agrotecnologia, 11, 2, 111-123. https://doi.org/10.5935/PAeT.V11.N2.12

Vasconcellos, S. M. de. 2005. Revisão dos gêneros Pronolpha e Segurigera (Orthoptera,
Romaleidae, Romaleinae). Iheringia. Série Zoologia, $\quad 95, \quad 2, \quad 133-149$. https://doi.org/10.1590/S007347212005000200004

Vendramini, J. M. B.; Dubeux, J. C. B.; Silveira, M. L. 2014. Nutrient cycling in tropical pasture ecosystems. Revista Brasileira de Ciências Agrárias, 9, 2, 308-315. https://doi.org/10.5039/agraria.v9i2a3730

Vidal, M. M.; Pivello, V. R.; Meirelles, S. T.; Mitzger, J. P. 2007. Produção de serapilheira em floresta Atlântica secundária numa paisagem fragmentada (Ibiúna, $\mathrm{SP}$ ): importância da borda e tamanho dos fragmentos. Revista Brasileira de Botânica, 30, 3, 521-532. https://doi.org/10.1590/S010084042007000300016

Vital, A. R. T.; Guerrini, I. A.; Franken, W. K.; Fonseca, R. C. B. 2004. Produção de serapilheira e ciclagem de nutrientes de uma floresta estacional semidecidual em zona ripária. Revista Árvore, 28, 6, 793-800. https://doi.org/10.1590/S010067622004000600004

Werneck, L. P. L. 1863. Memória sobre a fundação e custeio de uma fazenda na província do Rio de Janeiro. Segunda edição. 25p.

Woiciechowski, T.; Marques, R. 2017. Produção de serapilheira e restituição de nutrientes em florestas secundárias do litoral paranaense. Ecologia e Nutrição Florestal, 5, 2, 53-67.

Xuluc-Tolosa, F. J.; Vester, H. F. M.; RamírezMarcial, N.; Castellanos-Albores, J.; Lawrence, D. 2002. Leaf litter decomposition of tree species in three successional phases of tropical dry secondary forest in Campeche, Mexico. Forest Ecology and Management, 174, 1-3, 401-412. https://doi.org/10.1016/S0378-

1127(02)00059-2

Zhang, Y.; Gan, Z.; Li, R.; Wang, R.; Li, N.; Zhao, M.; Du, L.; Guo, S.; Jiang, J.; Wang, Z. 2015. Litter production rates and soil moisture influences interannual variability in litter respiration in the semi-arid Loess Plateau, China. Journal of Arid Environments, 125, 43-51. https://doi.org/10.1016/j.jaridenv.2015.09.01 6 